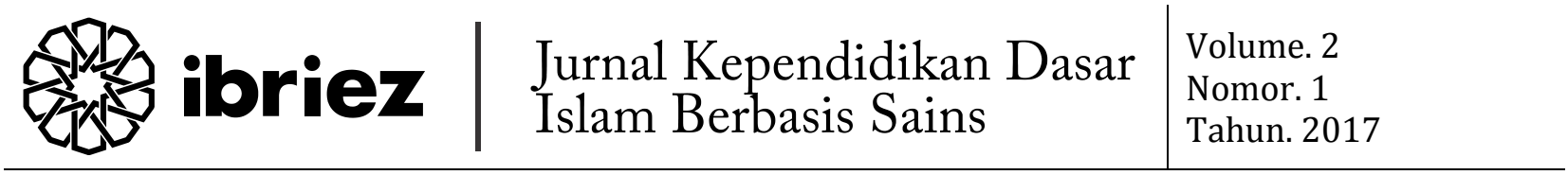

\section{Pengaruh Metode Pemberian Tugas (Resitasi) Terhadap Kemampuan Berpikir Kritis Siswa Pada Mata Pelajaran PKN Kelas IV SDN Mojoroto Kota Kediri}

\author{
Frans Aditia Wiguna \\ PGSD FKIP Universitas Nusantara PGRI Kediri \\ frans@unpkediri.ac.id
}

\begin{abstract}
Abstrak
Konsep pembelajaran berakar pada pihak pendidik dan konsep belajar berakar pada pihak peserta didik. Pendidik sebagai pengelola kegiatan belajar mengajar yang efektif. harus mengetahui dan menguasai setiap metode atau model pembelajaran. Guru dapat menggunakan metode tanya jawab, pemberian tugas (resitasi), metode diskusi, dan masih banyak pilihan metode yang dapat digunakan untuk keberhasilan suatu tujuan pendidikan. Oleh karena adanya kesenjangan antara teori dan praktik serta eratnya pemilihan metode pembelajaran yang harus relevan dengan peningkatan kemampuan berpikir kritis siswa maka menjadi penting untuk memilih dan menerapkan metode pembelajaran yang relevan dan efektif. Adapun tujuan dalam penelitian ini adalah untuk mengetahui seberapa besar pengaruh metode pemberian tugas (resitasi) terhadap kemampuan berpikir kritis siswa pada mata pelajaran PKn. Penelitian ini merupakan penelitian eksperimen, dengan menggunakan Pretest-Postest yang dilaksanakan di SDN 3 Mojoroto Kota Kediri (Kel. Eksperimen) dan SDN 6 Mojoroto Kota Kediri (Kel. Kontrol), dengan sasaran penelitian adalah siswa kelas IV, selanjutnya teknik analisis $t$-test digunakan untuk menguji hipotesis. Hasil temuan penelitian adalah: pretest rerata nilai pada kelas kontrol yaitu 51, dan rerata nilai pada kelas eksperimen yaitu 54. Mean pada tabel statistik Pretest kelompok eksperimen adalah 54,38 dengan Std. deviation 7,497, dan Std. deviation 7,594. Sedangkan Mean kelompok kontrol pada tabel statistik Pretest adalah 51,94 dengan Std. Deviation 8,532 dan kelas kontrol pada tabel statistik postest adalah 66,94 dengan Std. Deviation 8,234. Nilai rerata hasil belajar menggunakan metode pemberian tugas (resitasi) terhadap kemampuan berpikir kritis siswa untuk menyelesaikan soal PKn tentang globalisasi dengan menggunakan metode resitasi rerata pada kelas kontrol yaitu 66 dan Mean pada kelas eksperimen yaitu 74. Sehingga dapat disimpulkan adanya pengaruh yang signifikan metode pemberian tugas (resitasi) terhadap kemampuan berpikir kritis siswa pada mata pelajaran PKn kelas IV SDN Mojoroto Kota Kediri.
\end{abstract}

Kata Kunci : Pengaruh Model Pembelajaran, Pembelajaran Kooperatif Snowball Throwing, Hasil Belajar IPA 


\begin{abstract}
In learning science in elementary school requires a new innovation that is able to activate and make the learning process more enjoyable so that students are able to understand the material being studied. This requires teachers to be more creative and innovative in selecting a learning model that will be used. One example of learning model that can be used is a cooperative learning model Snowball Throwing. Throwing Snowball In lessons students will learn in groups and in collaboration with the group of their friends in solving problems. So that students can easily understand the material and also in expressing ideas that can maximize learning outcomes. This study aims to determine whether or not the influence of cooperative learning model with Snowball Throwing on learning outcomes of science in grade IV SDN Bondrang Sawoo District of Ponorogo in the academic year 2016/2017. Subjects in this study were students of class IV SDN 1 Bondrang and fourth grade students of SDN 2 Bondrang. In this study, using a quantitative approach to experimental research methods. Sampling was done by sampling research saturated. While the researchers to collect data using the test method, and documentation. Data analysis techniques used in this research is the prerequisite test and test hypotheses. The results showed that the application of learning models Snowball Throwing can affect learning outcomes IPA grade IV SDN Bondrang Ponorogo, where the result the average value of the experimental class was 83.23 and in control group was 71.47. The conclusions of this research is no effect of the application of cooperative learning model with Snowball Throwing on learning outcomes of science in grade IV SDN Bondrang Sawoo District of Ponorogo in the academic year $2016 / 2017$.
\end{abstract}

Keywords : Effects of Learning Model, Snowball Throwing Cooperative Learning, Learning Outcomes IPA

\section{A. PENDAHULUAN}

Menurut Undang-undang Sistem Pendidikan Nasional (Sisdiknas) Nomor 20 Tahun 2003 dijelaskan bahwa Pendidikan Nasional berfungsi untuk mengembangkan kemampuan dan membentuk watak serta peradaban bangsa yang bermartabat dalam rangka mencerdaskan kehidupan bangsa. Selain itu, disebutkan dalam Undang-undang tersebut bahwa Pendidikan Nasional bertujuan untuk mengembangkan potensi peserta didik agar menjadi manusia yang beriman dan bertaqwa kepada Tuhan Yang Maha Esa, berakhlak mulia, sehat, sehat, berilmu, cakap, kreatif, mandiri dan menjadi warga negara yang demokratis serta bertanggungjawab. ${ }^{1}$

Kualitas pendidikan perlu untuk terus ditingkatkan. Kualitas pendidikan ini terkait dengan kualitas proses dan kualitas hasil. Kualitas proses dapat dicapai apabila proses pembelajaran berlangsung secara efektif dan siswa dapat menghayati serta menjalani proses pembelajaran secara bermakna. Kualitas hasil dapat dilihat pada unjuk kerja siswa yang menunjukkan kecakapan hidup dan kompetensi dengan tingkat penguasaan yang tinggi; yang meliputi pemahaman dan penghayatan,

\footnotetext{
${ }^{1}$ Depdiknas, "UURI No. 20 Th. 2003 Tentang Sisdiknas Bab II Dasar, Fungsi dan Tujuan Pasal 3" (Depdiknas, 2003).
} 
pengetahuan, keterampilan, sikap, dan juga nilai-nilai terhadap tugas-tugas belajar sesuai dengan kebutuhan siswa dalam kehidupannya dan tuntutan yang ada di masyarakat (dunia kerja).

Peningkatan kualitas sumber daya manusia dalam sebuah bangsa juga tidak dapat dipisahkan dengan pendidikan. Pendidikan adalah usaha nyata untuk mengembangkan potensi sumber daya manusia (SDM). Sumber daya manusia dapat berkembang dengan baik apabila melalui pembelajaran yang baik pula.

Konsep belajar berakar pada pihak peserta didik dan konsep pembelajaran berakar pada pihak pendidik. Peserta didik adalah seseorang atau sekelompok orang sebagai pencari, penerima pelajaran yang dibutuhkannya, sedangkan pendidik adalah seseorang atau sekelompok orang yang berprofesi sebagai pengelola kegiatan belajar mengajar yang efektif.

Peningkatan kualitas sumber daya manusia dalam sebuah bangsa juga tidak dapat dipisahkan dengan pendidikan. Hal ini tidak dapat diabaikan karena pedididikan adalah dasar atau fondamen dari masyarakat yang berkualitas. ${ }^{2}$ Upaya peningkatan suber daya manusia tidak hanya dilakukan dengan memberikan sebuah pendidikan, akan tetapi harus disertai dengan peningkatan mutu pendidikan itu sendiri. Pembangunan pendidikan adalah sesuatu yang penting dalam rangka mewujudkan kualitas Sumber Daya Manusia. Suatu negara yang melaksanakan pembangunan mulai dari dunia pendidikan saat ini sudah tampak menunjukkan kemajuan yang pesat.

\footnotetext{
${ }^{2}$ Tilaar H. A. R, Standarisasi Pendidikan Nasional (Bandung: Rineka Cipta, 2006).
}

Menyadari pentingnya peningkatan kualitas SDM khususnya sekolah tingkat dasar (SD), pemerintah telah melakukan upaya-upaya diantaranya adalah dengan program-program peningkatan mutu pendidikan. Dalam bidang pendidikan pembenahan yang dilakukan antara lain;

1) dalam bidang sarana dan prasarana seperti pengadaan gedung dan buku pelajaran,

2) dalam bidang kompetensi tenaga kependidikan, dengan mengadakan pelatihan-pelatihan bagi kepala sekolah, guru, dan tenaga kependidikan lainnya,

3) dalam bidang kurikulum juga telah melakukan revisi terhadap kurikulum 1994 dievaluasi menjadi kurikulum 2004 yaitu kurikulum berbasis kompetensi (KBK) dan dalam waktu dekat hingga sekarang kurikulum yang diberlakukan adalah kurikulum tingkat satuan pendidikan (KTSP), bahkan berdasarkan pertimbangan dan pemikiran KTSP kembali mendapat perbaikan dengan hadirnya kurikulum 2013.

Salah satu upaya agar proses belajar mengajar dapat berjalan dengan lancar, guru harus mengetahui dan menguasai setiap metode atau model pembelajaran. Dalam hal ini guru tidak hanya menggunakan metode ceramahsaja dalam kegiatan belajar. Guru dapat menggunakan metode tanya jawab, pemberian tugas (resitasi), metode diskusi, dan masih banyak pilihan metode yang dapat digunakan untuk keberhasilan suatu tujuan pendidikan. Sebagaimana hal ini ditegaskan dalam Undang-Undang 20 Tahun 2003 pasal 3 tentang fungsi dan tujuan pendidikan, dimana Pendidikan nasional berfungsi mengembangkan 
kemampuan dan membentuk watak serta peradaban bangsa yang bermartabat dalam rangka mencerdaskan kehidupan bangsa, bertujuan untuk berkembangnya potensi peserta didik agar menjadi manusia yang beriman dan bertakwa kepada Tuhan Yang Maha Esa, berakhlak mulia, sehat, berilmu, cakap, kreatif, mandiri, dan menjadi warga Negara yang demokratis serta bertanggung jawab.

Metode pembelajaran dapat dipahami sebagai strategi dalam proses belajar mengajar. ${ }^{3}$ Metode pembelajaran adalah kerangka konseptual yang melukiskan prosedur yang sistematis dalam mengorganisasikan pengalaman belajar untuk mencapai tujuan pembelajaran tertentu, dan berfungsi sebagai pedoman bagi para perancang pembelajaran dan para pengajar dalam merencanakan dan melaksanakan aktivitas belajar mengajar.

Oleh karena itu, sebagai guru harus mencari atau memilih metode pembelajaran/ metode mengajar yang tepat dan sesuai dengan kondisi siswa serta materi yang disampaikan.

Metode pembelajaran yang sama dengan karakter siswa yang berbeda, hasilnya akan berbeda pula. Demikian juga untuk materi yang berbeda seorang guru tidak bisa menerapkan metode pembelajaran yang sama.

Metode pembelajaran yang dipilih diharapkan mempertimbangkan kemudahan bagi siswa dalam menangkap materi yang disampaikan oleh guru sehingga dapat diaplikasikan dalam

\footnotetext{
${ }^{3}$ Arief M. Sardiman, Interaksi \& motivasi belajar mengajar (Rajagrafindo Persada (Rajawali Pers), 2004).
}

kehidupan sesuai dengan kaidah yang berlaku. Hal tersebut hendaknya melibatkan dunia nyata sebagai suatu konteks belajar bagi siswa. Dengan demikian, penyajian suatu masalah yang autentik dan bermakna akan dapat memberikan kemudahan kepada siswa untuk melakukan penyelidikan dan penemuan.

Untuk mencapai tujuan pendidikan, maka dalam proses pembelajaran harus memperhatikan aspek-aspek yang mampu mencetak sumber daya manusia yang berkualitas sebagaimana yang diharapkan. Berdasarkan hasil observasi awal, ternyata kondisi pembelajaran yang nampak di SDN Mojoroto kota Kediri belum sesuai dengan harapan. Siswa belum dapat berpikir kritis tentang pembelajaran PKn. Hal ini menjadi tugas guru untuk memberikan bimbingan kepada siswa tentang cara berpikir kritis dalam memahami nilai-nilai pancasila dan budaya masyarakat Indonesia dalam pengaruh globalisasi. Untuk memperoleh informasi dan mengembangkan konsep-konsep sains, siswa belajar tentang bagaimana membangun kerangka masalah, menyusun fakta, menganalisis data, dan menyusun argumentasi terkait pemecahan masalah, kemudian memecahkan masalah, baik secara individual maupun dalam kelompok. ${ }^{4}$

Oleh karena adanya kesenjangan antara teori dan praktik serta eratnya pemilihan metode pembelajaran yang harus relevan dengan peningkatan kemampuan berpikir kritis siswa maka menjadi penting untuk memilih dan

\footnotetext{
${ }^{4}$ Hariyanto Warsono, Pembelajaran Aktif Teori dan Asesmen (Bandung: Remaja Rosdakarya, 2012).
} 
menerapkan metode pembelajaran yang relevan dan efektif. Berdasarkan uraian tersebut, maka peneliti sangat tertarik untuk melakukan penelitian dengan mengetengahkan judul Pengaruh Metode Pemberian Tugas (Resitasi) Terhadap Kemampuan Berpikir Kritis Siswa Pada Mata Pelajaran PKn Kelas IV SDN Mojoroto Kota Kediri.

Permasalahan dalam penelitian ini yang dapat dirumuskan adalah "Apakah ada pengaruh metode pemberian tugas (resitasi) terhadap kemampuan berpikir kritis siswa. Adapun tujuan dalam penelitian ini adalah untuk mengetahui seberapa besar pengaruh metode pemberian tugas (resitasi) terhadap kemampuan berpikir kritis siswa. Hipotesis dalam penelitian ini adalah adanya pengaruh yang signifikan metode pemberian tugas (resitasi) terhadap kemampuan berpikir kritis siswa.

\section{B. Hakikat Pembelajaran PKn}

Terkait dengan naskah lampiran Permendiknas No.22 tahun 2006 tentang Standar Isi di sebutkan bahwa mata pelajaran Pendidikan kewarganegaraan merupakan mata pelajaran yang memfokuskan pada pembentukan warganegara yang memahami dan mampu melaksanakan hak-hak dan kewajibannya untuk menjadi warga negara Indonesia yang cerdas, terampil, dan berkarakter yang diamanatkan oleh Pancasila dan UUD 1945. ${ }^{5}$ Sedangkan dalam rumusan naskah Kurikulum 2004 menyatakan bahwa Kewarganegaraan (Citizenship) meru-

\footnotetext{
${ }^{5}$ Depdiknas, "Permendiknas RI No. 22. Tentang Standar Isi Untuk Satuan Pendidikan Dasar Dan Menengah" (Depdiknas, n.d.).
}

pakan mata pelajaran yang memfokuskan pada pembentukan diri yang beragam dari segi

agama, sosio-kultural, bahasa, usia dan suku bangsa untuk menjadi warga negara yang cerdas, terampil, dan berkarakter seperti yang diamanatkan oleh Pancasila dan UUD $1945 .^{6}$

Pendidikan Kewarganegaraan telah mengalami perkembangan sejarah yang sangat panjang, secara konseptual istilah Pendidikan Kewarganegaraan dimulai dari Kewarganegaraan (1956), Civic (1959), Kewarganegaraan (1962), Pendidikan Kewarganegaraan (1968), Pendidikan Moral Pancasila (1975), Pendidikan Pancasila Kewarganegaraan (1994), Pendidikan Kewarganegaraan (UU No.20 Tahun 2003).

Pendidikan Kewarganegaraan dapat diartikan sebagai wahana untuk mengembangkan dan melestarikan nilai luhur dan moral yang berakar pada budaya bangsa Indonesia yang diharapkan dapat diwujudkan dalam bentuk perilaku kehidupan berbangsa dan bernegara.

Landasan PKn adalah Pancasila dan UUD 1945, yang berakar pada nilai-nilai agama, kebudayaan nasional Indonesia, serta tanggap pada perubahan zaman. Selain itu juga dari Undang-undang No. 20 Tahun 2003 tentang Sistem Pendidikan Nasional, Kurikulum Berbasis Kompetensi tahun 2004 serta Pedoman Khusus Pengembangan Silabus dan Penilaian Mata Pelajaran Kewarganegaraan yang diterbitkan oleh Departemen Pendidikan Nasional-Direktorat Jenderal Pendidikan

\footnotetext{
${ }^{6}$ Enco Mulyasa, Kurikulum berbasis kompetensi: konsep, karakteristik, dan implementasi (PT Remaja Rosdakarya, 2002).
} 
Dasar Menengah-Direktorat Pendidikan Menengah Umum.

Tujuan mata pelajaran Pendidikan Kewarganegaraan adalah sebagai berikut: 1) Berpikir secara kritis, rasional, dan kreatif dalam menanggapi isu kewarganegaraan; 2) Berpartisipasi secara bermutu dan bertanggung jawab, serta bertindak secara cerdas dalam kegiatan bermasyarakat, berbangsa, dan bernegara; 3) Berkembang secara positif dan demokratis untuk membentuk diri berdasarkan pada karakter-karakter masyarakat Indonesia agar dapat hidup bersama dengan bangsa-bangsa lain, dan 4) Berinteraksi dengan bangsa-bangsa lain dalam peraturan dunia secara langsung dengan memanfaatkan teknologi informasi dan komunikasi. ${ }^{7}$

Sementara itu, PKn di Indonesia diharapkan dapat mempersiapkan peserta didik menjadi warga negara yang memiliki komitmen yang kuat dan konsisten untuk mempertahankan Negara Kesatuan Republik Indonesia (NKRI). PKn merupakan usaha untuk membekali peserta didik dengan pengetahuan dan kemampuan dasar yang berkenaan dengan hubungan antara warga negara dengan negara serta pendidikan pendahuluan bela negara agar menjadi warga negara agar dapat diandalkan oleh bangsa dan negara. ${ }^{8}$ Dari pengertian pendapat di atas dapat disimpulkan PKn merupakan mata pelajaran yang berfokus pada pembinaan karakter warga negara dalam perspektif

\footnotetext{
${ }^{7}$ Depdiknas, "Kurikulum Tingkat Satuan Pendidikan (KTSP) Untuk Sekolah Dasar/ MI.” (Depdiknas, 2006).

${ }^{8}$ Muhammad Numan Soemantri, Menggagas pembaharuan pendidikan IPS (Bandung: Remaja Rosdakarya, 2001), 154 dan 158.
}

kenegaraan, dengan harapan melalui mata pelajaran PKn ini dapat terbina insan warga negara yang baik (GoodCitizenship). Dijelaskan pula unsur terkait dengan pengembangan PKn, antara lain: a) hubungan pengetahuan interseptif (intaceptive knowledge) dengan pengetahuan ekstraseptif (extraceptive knowlede) atau antara agama dan ilmu; b) kebudayaan Indonesia dan tujuan pendidikan nasional; c) disiplin ilmu pendidikan terutama psikologi pendidikan; d) disiplin ilmu-ilmu sosial, khususnya "ide fundamental" ilmu Kewarganegaraan; e) dokumen negara, khususnyanya Pancasila, UUD 1945 dan perundangan negara serta sejarah perjuangan bangsa; f) kegiatan dasar manusia dan; g) pengertian pendidikan IPS. ${ }^{9}$

Ketujuh unsur diatas nantinya akan mempengaruhi pengembangan PKn. Karena pengembangan dalam PKn akan mempengaruhi pengertian PKn sebagai salah satu tujuan IPS.

Sehubungan dengan itu, PKn sebagai salah satu tujuan pendidikan IPS yang menekankan pada nilai-nilai untuk menumbuhkan warga Negara yang baik, patriotik, lebih lanjut dipaparkan batasan pengertian PKn sebagai berikut: salah satu tujuan pendidikan IPS. Pendidikan Kewarganegaraan adalah seleksi dan adaptasi dari disiplin ilmu-ilmu sosial, ilmu kewarganegaraan, humaniora, dan kegiatan dasar manusia, yang diorganisasikan dan disajikan secara psiologis dan ilmiah untuk ikut mencapai

\footnotetext{
${ }^{9}$ Soemantri, Menggagas pembaharuan pendidikan IPS.
} 
salah satu tujuan pedidikan IPS. ${ }^{10}$ Selain itu tujuan dari PKn yang pernah dikemukakan adalah sebagai berikut: a) Secara umum tujuan PKn harus ajeg dan mendukung keberhasilan pencapaian Pendidikan Nasional, yaitu: "mencerdaskan kehidupan bangsa yang mengembangkan manusia Indonesia seutuhnya. Yaitu manusia yang beriman dan bertaqwa kepada Tuhan Yang Maha Esa dan berbudi pekerti luhur, memiliki kemampuan pengetahuan dan keterampilan, kesehatan jasmani dan rohani, kepribadian mantap dan mandiri serta rasa tanggung jawab kemasyarakatan dan kebangsaan". b) Secara khusus. Tujuan PKn yaitu membina moral yang diharapkan diwujudkan dalam kehidupan sehari-hari yaitu perilaku yang memancarkan iman dan taqwa terhadap Tuhan Yang Maha Esa dalam masyarakat yang terdiri dari berbagai golongan agama, perilaku yang mendukung kerakyatan yang mengutamakan kepentingan bersama diatas kepentingan perseorangan dan golongan sehingga perbedaan pemikiran pendapat ataupun kepentingan diatasi melalui musyawarah mufakat, serta perilaku yang mendukung upaya untuk mewujudkan keadilan sosial seluruh rakyat Indonesia. ${ }^{11}$

Sedangkan tujuan pendidikan kewarganegaraan adalah, Partisipasi yang penuh nalar dan tanggung jawab dalam kehidupan politik dari warga negara yang taat kepada nilai-nilai dan prinsip-prinsip dasar demokrasi konstitusional Indonesia partisipasi warga negara yang efektif dan

\footnotetext{
${ }^{10}$ Ibid., 159.

${ }^{11}$ A. Kosasih Djahiri, Dasar-dasar Umum Metodologi dan Pengajaran Nilai Moral (Bandung: IKIP Bandung, 1995), 10.
}

penuh tanggung jawab memerlukan penguasaan seperangkat ilmu pengetahuan dan keterampilan intelektual serta keterampilan untuk berperan serta. Partisipasi yang efektif dan bertanggung jawab itu pun ditingkatkan lebih lanjut melalui pengembangan disposisi atau watak-watak tertentu yang meningkatkan kemampuan individu berperan serta dalam proses politik dan mendukung berfungsinya sistem politik yang sehat serta peraikan masyarakat. ${ }^{12}$ Sehubungan dengan era globalisasi, dimana semua telah berkembang dengan segala kecanggihannya. Siswa harus diperkenalkan dengan segala bentuk globalisasi baik di bidang komunikasi, transportasi, politik, dan perekonomian. Siswa harus memahami segala pengaruh baik atau buruk dari globalisasi tersebut agar menjadi manusia yang bertanggung jawab berdasarkan nilai-nilai Pancasila.

\section{Metode Resitasi}

Metode pembelajaran adalah suatu pengetahuan tentang cara-cara mengajar yang dipergunakan oleh guru atau instruktur. ${ }^{13}$ Pengertian lain mengatakan pelajaran kepada siswa di dalam kelas, baik secara individual ataupun secara kelompok agar pelajaran itu dapat diserap, dipahami dan dimanfaatkan oleh siswa dengan baik.

Gagne berpendapat bahwa metode pembelajaran adalah serangkaian kegiatan yang dirancang untuk memungkinkan

\footnotetext{
${ }^{12}$ Sapriya, “Analisis Signifikasi 'Content' PKn Persekolahan Dalam Menghadapi Tuntutan Era Demokrasi dan Penegakan Hak Asasi Manusia," Jurnal Civicus 1 (2001): 57-72.

${ }^{13}$ Abu Ahmadi dan Joko Tri Prasetya, Strategi belajar mengajar (Bandung: Pustaka Setia, 2005), 52.
} 
terjadinya proses belajar pada siswa. ${ }^{14}$ Dapat disimpulkan bahwa metode pembelajaran adalah metode yang digunakan oleh guru sebagai cara untuk mencapai tujuan pembelajaran yang telah ditetapkan. Hal ini mendorong seorang guru untuk mencari metode yang tepat dalam penyampaian materinya agar dapat diserap dengan baik oleh siswa. mengajar secara efektif sangat bergantung pada pemilihan dan penggunaan metode mengajar.

Metode resitasi merupakan salah satu pilihan metode mengajar seorang guru, dimana guru memberikan sejumlah item tes kepada siswanya untuk dikerjakan. Pemberian item tes ini biasanya diberikan pada akhir setiap pertemuan atau akhir pelajaran. Pemberian tugas merupakan salah satu alternatif untuk menyempurnakan penyampaian tujuan pembelajaran. Hal ini disebabkan oleh padatnya materi pelajaran yang harus disampaikan sementara waktu belajar sangat terbatas.

Salah satu metode yang digunakan dalam pelajaran PKn adalah metode resitasi. Metode resitasi adalah cara untuk mengajar yang dilakukan dengan jalan memberi tugas khusus kepada siswa. Pelaksanaannya bisa di kelas, di perpustakaan, di laboratorium, atau yang ada hubungannya dengan tugas tersebut dan hasilnya dipertanggung-jawabkan. ${ }^{15}$ Untuk penelitian ini lebih difokuskan metode resitasi dilakukan di dalam kelas.

\footnotetext{
${ }^{14}$ Udin Saripudin Winataputra et al., "Materi dan pembelajaran PKN SD," 2014,

http://repository.ut.ac.id/4114/1/PDGK4401-TM.pdf.

${ }^{15}$ Imansyah Alipandie, Didaktik Metodik Pendidikan

(Surabaya: Penerbit Usaha Nasional, 1984), 93.
}

Metode pemberian tugas merupakan suatu aspek dari metode-metode mengajar. Karena tugas-tugas meninjau pelajaran baru, untuk menghafal pelajaran yang sudah diajarkan, untuk latihanlatihan, untuk memecahkan suatu masalah dan seterusnya. ${ }^{16}$

Siswa yang kurang menguasai materi pembelajaran tentu akan mempunyai nilai yang lebih rendah dibandingkan dengan siswa yang lebih menguasai materi ajar.

Untuk menguasai materi ajar maka dituntut adanya aktifitas dari siswa yang bukan hanya sekedar mengingat, tetapi lebih dari itu yakni memahami, mengaplikasikan, menganalisis, mensintesis, dan mengevaluasi materi ajar.

Setiap metode memiliki kelebihan dan kekurangan, sehingga ketepatan guru dalam memilih metode pembelajaran sangat diperlukan agar kekurangan tersebut tidak menjadi kendala yang dapat menghambat ketuntasan belajar siswa.

Metode resitasi ini dianggap efektif, bila hal-hal berikut ini dilaksanakan yaitu : merumuskan tujuan khusus yang hendak dicapai, tugas yang diberikan harus jelas, dan waktu yang disediakan untuk menyelasaikan tugas harus cukup. ${ }^{17}$

Langkah-langkah yang ditempuh dalam pendekatan pelaksanaan metode resitasi yaitu: 1) Tugas yang diberikan harus jelas; 2) Tempat dan lama waktu penyelesaian tugas harus jelas; 3) Tugas yang diberikan terlebih dahulu dijelaskan/ diberikan petunjuk yang jela, agar siswa yang belum mampu memahami tugas itu berupaya

\footnotetext{
${ }^{16}$ I.LPasaribu, Didaktik dan Metodik (Bandung: Tarsito, 1986), 108.

${ }^{17}$ Alipandie, Didaktik Metodik Pendidikan, 93.
} 
untuk menyelesaikannya; 4) Guru harus memberikan belajar atau salah arah dalam mengerjakan tugas; 5) Memberi dorongan terutama bagi siswa yang lambat atau kurang bergairah mengerjakan tugas. ${ }^{18}$ Adapun kelebihan metode penugasan (resitasi) dapat disebutkan sebagai berikut: 1) Tugas lebih merangsang siswa untuk belajar lebih banyak, baik pada waktu di kelas maupun di luar kelas; 2) Metode ini dapat mengembangkan kemandirian siswa

yang diperlukan di kehidupan kelak; 3) Tugas dapat lebih meyakinkan tentang apa yang dipelajari dari guru, lebih memperdalam, memperkaya/memperluas pandangan tentang apa yang dipelajari; 4) Tugas dapat membina kebiasaan siswa untuk mencari dan mengolah sendiri informasi dan komunikasi, dan 5) Metode ini dapat membuat siswa bergairah dalam belajar karena kegiatan belajar dilakukan dengan berbagai variasi sehingga tidak membosankan.

Sedang kekurangan dari metode penugasan (resitasi) adalah: 1) Siswa sulit dikontrol, apa benar mengerjakan tugas ataukah dikerjakan orang lain; 2) Tidak mudah memberikan tugas yang sesuai dengan perbedaan individu siswa; 3) Sering memberikan tugas yang monoton, sehingga membosankan. ${ }^{19}$

\section{Kemampuan Berpikir Kritis}

Berpikir diperlukan oleh manusia dalam kehidupan sehari-hari. Melalui berpikir manusia dapat mengenali masalah, memahami, dan memecahkan-

\footnotetext{
${ }^{18} \mathrm{~N}$. Sudirman, Ilmu pendidikan (Bandung: Tarsito, 1992), 145.

${ }^{19}$ Ibid., 142.
}

nya. Berpikir itu sendiri memiliki empat aspek yaitu penyusunan konsep, pemecahan masalah, penalaran formal, dan pengambilan keputusan tingkat tinggi.

Berpikir adalah daya jiwa yang dapat meletakkan hubungan-hubungan antara pengetahuan, merupakan proses yang "dialektis" yang bahwa selama berpikir, pikiran dalam keadaan tanya jawab, untuk dapat meletakkan hubungan pengetahuan. Berpikir kritis sangat diperlukan dalam era globalisasi seperti sekarang ini untuk menyelesaikan sebuah permasalahan yang komplek dalam kehidupan modern ini.

Kegiatan berpikir dilakukan guna memahami realitas dalam rangka antara lain: 1) Mengambil keputusan; 2) Memecahkan Persoalan, dan 3) Menghasil-kan sesuatu yang baru. Memahami realitas berarti menarik kesimpulan serta berbagai kemungkinan penjelasan dari realitas eksternal dan internal. Berpikir kritis merupakan salah satu keterampilan tingkat tinggi yang sangat penting diajarkan kepada siswa selain keterampilan berpikir kreatif.

Berpikir adalah suatu kegiatan mental yang melibatkan kerja otak. Walaupun tidak bisa dipisahkan dari aktivitas kerja otak, pikiran manusia lebih dari sekedar kerja organ tubuh yang disebut otak. Memikirkan sesuatu berarti mengarahkan diri pada objek tertentu, menyadari secara aktif dan menghadirkannya dalam pikiran kemudian mempunyai wawasan tentang objek tersebut. ${ }^{20}$

Pengertian berpikir kritis adalah berpikir pada sebuah level yang kompleks dengan menggunakan berbagai proses

\footnotetext{
${ }^{20}$ Abu Ahmadi, Psikologi umum (Jakarta: Rineka Cipta, 2003), 120.
} 
analisis dan proses evaluasi terhadap informasi yang didapatkan.

Definsi tentang berpikir kritis yang dikemukakan para ahli, diantaranya Chaffe berpikir kritis adalah berpikir untuk menyelidiki secara sistematis proses berpikir itu sendiri. Maksudnya tidak hanya memikirkan dengan sengaja, tetapi juga meneliti bagaimana kita dan orang lain menggunakan bukti dan logika. ${ }^{21}$ Bimbingan utamanya kepada siswa yang mengalami kesulitan Berpikir kritis merupakan kegiatan mengevaluasi dalam mempertimbangkan kesimpulan yang akan diambil dengan beberapa faktor pendukung untuk membuat keputusan. Selain itu, berpikir kritis adalah logis dan reflektif yang difokuskan pada pengambilan keputusan mengenai hal yang akan dipercaya/ dilakukan.

Berpikir kritis adalah berpikir secara beralasan dan reflektif dengan menekankan pembuatan keputusan tentang apa yang harus dipercayai atau dilakukan. Berikut adalah contoh-contoh kemampuan berpikir kritis, misalnya 1) membanding dan membedakan, 2) membuat kategori, 3) meneliti bagian-bagian kecil dan keseluruhan, 4) menerangkan sebab, 5) membuat sekuen/urutan, 6) menentukan sumber yang dipercayai, dan 7) membuat ramalan. ${ }^{22}$

\footnotetext{
${ }^{21}$ Suriadi, "Pembelajaran dengan Pendekatan Discovery yang Menekankan Aspek Analogi Untuk Meningkatkan Pemahaman Matematik dan Kemampuan Berpikir Kritis Siswa SMA.” (Universitas Pendidikan Indonesia, 2006).

${ }^{22}$ Mustaji, "Pengembangan Kemampuan Berpikir Kritis dan Kreatif dalam Pembelajaran," diakses 4 Juni 2017,

http://www.academia.edu/3782126/Pengembangan_K emampuan_Berpikir_Kritis_dan_Kreatif_dalam_Pem belajaran.
}

Definisi tersebut mengimplikasikan lima hal 1) berpikir logis dengan menggunakan alasan-alasan yang baik; 2) berpikir reflektif dengan secara sadar mencari dan menggunakan alasan-alasan yang baik; 3) berpikir terfokus, yaitu berpikir untuk tujuan tertentu; 4) pengambilan keputusan mengenai hal yang akan dipercaya atau diyakini dengan mengevaluasi pernyataan atau perbuatan; 5) kecenderungan dan kemampuan, yaitu kemampuan kognitif dan kecenderungan untuk menggunakan kemampuan tersebut. $^{23}$

Dari beberapa pendapat para ahli di atas mengenai berpikir kritis, maka dapat diartikan bahwa berpikir kritis merupakan sebuah proses aktif dan cara berpikir secara teratur serta secara sistematis guna memahami informasi yang secara mendalam, sehingga kemudian membentuk sebuah keyakinan tentang kebenaran dari informasi atau pendapat-pendapat yang disampaikan. Proses aktif menunjukkan bahwa keinginan dan atau motivasi guna menemukan jawaban serta mencapai pemahaman. $^{24}$

\section{Rancangan dan Desain Penelitian}

Pada penelitian ini menggunakan rancangan eksperimen murni dengan alasan yaitu lebih memberikan perlakuan khusus terhadap kelompok eksperimen yakni pembelajaran menggunakan metode resitasi dan hanya melakukan kontrol pada kelompok lain. Dimana eksperimen murni adalah rancangan yang melibatkan

\footnotetext{
${ }^{23}$ Anthony J. Nitko, Educational assessment of students (ERIC, 2001), 65-66, http://eric.ed.gov/?id=ED449193.

${ }^{24}$ Hendra Surya, Cara Belajar Orang Genius (Jakarta: : Elex Media Komputindo, 2013), 159.
} 
satu variabel eksperimen yang berkaitan diberikan perlakuan khusus (manipulasi) dan satu kelompok kontrol dengan perlakuan yang berbeda setelah itu menguji hasilnya.

Desain penelitian yang digunakan adalah suatu rancangan pretest dan postest yang dilaksanakan pada dua kelompok, yaitu kelompok eksperimen dan kelompok kontrol. Sebagaimana terlihat dalam Tabel 3.1 berikut ini.

Tabel 3. 1 Rancangan Penelitian

\begin{tabular}{|l|c|c|c|}
\hline Kelompok & Pretest & Perlakuan & Postest \\
\hline Eksperimen & Y1 & $\mathrm{X}$ & $\mathrm{Y} 2$ \\
\hline Kontrol & $\mathrm{Y} 1$ & - & $\mathrm{Y} 2$ \\
\hline
\end{tabular}

Keterangan:

$\mathrm{Y} 1=$ Pretest

$\mathrm{Y} 2=$ Postest

$\mathrm{X}=$ Perlakuan, yaitu penerapan metode Resitasi terhadap kemampuan berpikir kritis pada mata pelajaran $\mathrm{PKn}$

$\mathrm{Y} 1$ = Y2 (butir soal Y1 sama dengan Y2)

Ditinjau dari perannya variabel penelitian terdiri dari variabel bebas, variabel terikat dan variabel perantara. Variabel penelitian adalah objek penelitian, atau apa yang menjadi titik perhatian suatu penelitian. ${ }^{25}$ Pada penelitian ini, variabel yang digunakan adalah variabel bebas dan variabel terikat. Variabel bebas yang biasanya dinyatakan tanda huruf (X), adalah variabel yang mempengaruhi atau menjadi penyebab bagi variabel yang lain, dalam penelitian ini adalah Metode Tanya Jawab (Resitasi). Variabel terikat yang biasanya dinyatakan tanda huruf (Y), adalah variabel yang dipengaruhi atau disebabkan bagi variabel yang lain.

Populasi adalah jumlah dari keseluruhan subjek penelitian. ${ }^{26}$

\footnotetext{
${ }^{25}$ Arikunto Suharsimi, Prosedur Penelitian Suatu Pendekatan Praktek (Jakarta: Rineka Cipta, 2006), 56. ${ }^{26}$ Ibid., 130.
}

Berdasarkan definisi tersebut di atas, maka dapat disimpulkan bahwa populasi adalah keseluruhan individu atau objek penelitian yang di duga memiliki sifat dan karakteristik yang sama dan menjadi keberlakuan kesimpulan dalam penelitian. Dalam penelitian ini yang menjadi populasi adalah siswa kelas IV SDN Mojoroto Kota kediri. Adapun siswa kelas IV SDN Mojoroto 1 kota kediri dengan jumlah siswa 32 orang sebagai kelas uji coba, kelas IV SDN Mojoroto 3 dengan jumlah siswa 32 orang sebagai kelompok eksperimen dan siswa kelas IV SDN Mojoroto 6 dengan jumlah siswa 31 orang sebagai kelompok kontrol. Alasan memilih kelas tersebut karena mempunyai karakteristik yang sama, antara lain: 1) Sasaran yang diteliti disamakan kelasnya, yaitu pada kelas IV SDN Mojoroto Kota Kediri; 2) Kelas eksperimen dan kelas kontrol terdapat pada satu lembaga yang sama, yaitu SDN Mojoroto kota Kediri; 3) Jumlah dan usia siswa pada kelas eksperimen dan kelas kontrol relatif sama; 4) Ruangan kelas kedua kelompok eksperimen dan kontrol itu tidak ada perbedaan kebisingan, kepengapan, karena ventilasi yang kurang, tata ruang, dan tata cahaya; 5) Siswanya mempunyai kemampuan yang sama dalam $\mathrm{PKn}$, dengan rerata nilai siswa

antara 70-75 dan 6) Untuk memantapkan karakteristik yang sama, maka dilakukan dengan uji-t.

Kegiatan penelitian dirincikan dalam tiga tahapan sebagai berikut: 1. Tahap Persiapan (Tahap Awal) di mana dalam tahap ini ada dua kegiatan utama dalam tahap persiapan atau tahap awal ini, yaitu: (a) Penyusunan perangkat yang meliputi: Studi literatur dan studi lapangan; 
Menentukan lokasi penelitian; Penyusunan proposal penelitian. Kegiatan selanjutnya adalah (b) Pengembangan instrumen penelitian yang meliputi: Pemilihan sampel; Menyusun topik dan subjek penelitian; Menyusun instrumen penelitian; Validasi eksperimen; Revisi instrumen; Menyiapkan instrumen dan administrasi penelitian. 2. Tahap Pelaksanaan Penelitian, dimana dalam tahap ini meliputi kegiatan: (a) Melakukan uji coba pada instrumen tes yang akan digunakan; (b) Memberikan tes awal kepada kedua kelas; (c) Pelaksanaan pembelajaran PKn di kelas eksperimen dengan pembelajaran berorientasi pada metode pemberian tugas (resitasi) yang diawali dengan penjelasan materi pada siswa dengan metode ceramah, serta kelas kontrol hanya menggunakan metode pembelajaran ceramah (konvensional); (d) Pemberian tes akhir pada kedua kelas untuk mengetahui tingkat ketercapaian kemampuan berpikir kritis; dan (e) Pengisian angket oleh siswa pada kelompok eksperimen untuk mengetahui tanggapan dan antusiasme siswa terhadap komponen dan cara pembelajaran berorientasi pada metode pemberian tugas (resitasi). Selanjutnya tahap terakhir yaitu:

3. Tahap Penyelesaian (Tahap Akhir), dimana dalam tahap ini ada dua kegiatan yaitu: (a) Mengelola dan menganalisis data hasil penelitian dan (b) Menyusun laporan penelitian

Tempat yang dijadikan penelitian oleh peneliti adalah SDN Mojoroto kota Kediri. Penelitian direncanakan akan dilakukan pada tanggal 23 bulan Januari. Analisis data dilakukan setelah data terkumpul. Proses analisis data merupakan usaha untuk memperoleh jawaban dari permasalahan penelitian. Sebagaimana mengetahui analisis statistik akan berwujud angka-angka, begitu pula dengan uji statistiknya. Metode statistik yang dipakai untuk menguji hipotesis kerja adalah menggunakan Uji-t sampel berpasangan dengan bantuan program SPSS. Analisis kemampuan berpikir kritis. Analisis data:

a. Validitas adalah suatu ukuran yang menunjukkan tingkat-tingkat kevalidan atau kesahihan sesuatu instrumen. Suatu instrumen yang valid atau sahih mempunyai validasi tinggi. Sebaliknya, instrumen yang kurang valid berarti memiliki validitas rendah. ${ }^{27}$

b. Reliabilitas tes adalah tingkat keajegan (konsistensi) suatu tes, yakni sejauh mana suatu tes dapat dipercaya untuk menghasilkan skor yang ajek/ konsisten (tidak berubah-ubah). Tes yang reliabel atau dapat dipercaya adalah tes yang menghasilkan skor ajeg, relatif tidak berubah walaupun di teskan pada situasi dan waktu yang berbeda-beda. Reliabilitas instrumen soal uraian pada penelitian ini menggunakan rumus Alpha, yaitu:

$r_{i i}=\left[\frac{k}{(k-1)}\right]\left[1-\frac{\Sigma \vartheta_{b}^{2}}{\vartheta_{t}^{2}}\right]$

Keterangan:

Rii = reliabilitas instrumen

$\mathrm{k}=$ banyaknya butir pertanyaan

$\Sigma \vartheta_{b}^{2}$ = jumlah varians butir

$\vartheta_{t}^{2} \quad=$ varians total

${ }^{27}$ Ibid., 108. 
Adapun kriteria reliabilitas instrumen ditentukan sebagai berikut ${ }^{28}$ :

$\begin{array}{lll}\mathrm{r}<0,40 & =\text { derajat } & \text { reliabilitas } \\ \text { rendah } & & \\ 0,40 \leq \mathrm{r}<0,80 & =\text { derajat } & \text { reliabilitas } \\ \text { sedang } & & \\ 0,80 \leq \mathrm{r} & =\text { derajat reliabilitas tinggi }\end{array}$

Uji normalitas digunakan untuk menentukan penggunaan statistik uji parametrik dan non-parametrik. Uji parametrik apabila menunjukkan data berdistribusi normal, sedangkan apabila data menunjukkan berdistribusi tidak normal, maka menggunakan uji nonparametrik. Untuk melakukan uji normalitas dalam penelitian ini menggunakan rumus che-square (X2), dengan kriteria apabila probabilitas (sig) lebih besar dari $(0,05)$, maka hasil tes dikatakan berdistribusi normal.

Rumus untuk menghitung che-square adalah sebagai berikut:

$\mathrm{X}^{2}=\sum \quad \frac{\left(f_{0}-f_{\mathrm{n}}\right)^{2}}{f_{h}}$

Keterangan:

fo $=$ frekuensi yang diamati

$\mathrm{fh}=$ frekuensi yang diharapkan

Uji normalitas juga digunakan program SPSS 20

Dalam penelitian perlu dilakukan pengujian terhadap kesamaan (homogenitas) beberapa bagian sampel. Pengujian yang dilakukan adalah pengujian dengan menggunakan tes awal yaitu uji homogenitas pada kelompok kelas dalam populasi yang bertujuan untuk mengetahui homogenitas pada kelompok kelas dalam populasi yang bertujuan untuk mengetahui homogenitas

${ }^{28}$ Ibid., 105. varians populasi, yang nantinya akan digunakan dalam penentuan kelas sampel. Pengujian ini dianalisis dengan menggunakan uji Bartlett. ${ }^{29}$ Adapun rumus Bartlett:

$$
\mathrm{X}^{2}=(\operatorname{In} 10)\left[\mathrm{B}-\sum\left(\mathrm{n}_{\mathrm{i}}-1\right) \log \mathrm{s}_{\mathrm{i}}^{2}\right]
$$

Keterangan:

$\mathrm{n}_{\mathrm{i}}=$ jumlah anggota dari kelas ke-i

$\mathrm{S}_{\mathrm{i}}=$ variansi kelas ke-i

dengan In $10=2,3026$ dan harga-harga lain yang perlu dihitung:

1. Variansi tiap-tiap sampel

$$
S_{i}^{2}=\frac{n \sum x_{i}^{2}-\left(\sum x_{i}\right)^{2}}{n(n-1)}
$$

2. Variansi gabungan dari seluruh sampel $s^{2}=\frac{\sum\left(n_{i}-1\right) s i^{2}}{\sum\left(n_{i}-1\right)}$

3. Harga satuan $B$ dengan rumus $\mathrm{B}=\left(\log \mathrm{s}^{2}\right) \sum\left(\mathrm{n}_{\mathrm{i}}-1\right)$

Pengujian hipotesis dilakukan pada taraf nyata $\alpha=0,05$ dengan $\mathrm{H}_{0}: \sigma_{1}^{2}=\sigma_{2}^{2}=$ $\sigma_{3}{ }^{2}$. Kriteria penerimaan dan penolakan hipotesis adalah:

$\mathrm{H}_{0}$ diterima jika $\mathrm{x}^{2} \mathrm{hit}<\mathrm{x}^{2}(1-\sigma)(\mathrm{k}-1)$

$\mathrm{H}_{0}$ ditolak jika $\mathrm{x}^{2} \mathrm{hit} \geq \mathrm{x}^{2}(1-\sigma)(\mathrm{k}-1)$

a. Secara Inferensial, dengan Uji-t. Dimana Untuk menguji hipotesis pada penelitian ini digunakan uji t. uji t merupakan uji hipotesis untuk membandingkan dua keadaan atau dua keadaan diketahui, dengan cara menguji kesamaan dua rerata populasi. Dimana Rumus Uji $t$ yang digunakan adalah ${ }^{30}$ :

\footnotetext{
${ }^{29}$ Sudjana, Metoda Statistika, 6 ed. (Bandung: Tarsito, 1997), 263.

${ }^{30}$ Suharsimi, Prosedur Penelitian Suatu Pendekatan Praktek.
} 


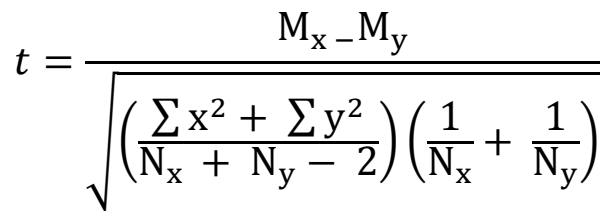

Keterangan:

$\mathrm{M}=$ nilai rerata hasil perkelompok

$\mathrm{N}$ = banyaknya subjek

$\mathrm{X}=$ deviasi setiap nilai $\mathrm{x}_{2}$ dan $\mathrm{x}_{1}$

$\mathrm{Y}=$ deviasi setiap nilai $\mathrm{y}_{2}$ dari mean $\mathrm{y}_{1}$

\section{Hasil Penelitian}

Uji validitas instrumen ini dilakukan dengan menghitung korelasi nilai tiap item terhadap nilai total sehingga diperoleh $r$ hitung untuk tiap item. Pengujian validitas ini dilakukan dengan teknik Pearson Correlation. Selanjutnya untuk menetapkan valid tidaknya tiap item instrumen, nilai r-hitung akan dibandingkan dengan $r$ kritis tabel $(0,349)$ menunjukkan bahwa item tersebut valid. ${ }^{31}$ Dari perhitungan inilah diputuskan dapat tidaknya item tersebut digunakan untuk mengambil data dalam penelitian.

- Jika r-hitung $\geq \mathrm{r}$ kritis $(0,349)$, maka item tersebut dinyatakan signifikan, jadi dapat dinyatakan valid sehingga layak untuk digunakan dalam penelitian.

- Jika r-hitung < r kritis $(0,349)$, maka item tersebut dinyatakan tidak signifikan, jadi tidak cukup valid sehingga harus drop, direvisi atau diganti.

Selanjutnya proses analisis validitas sebagaimana secara rinci dari seluruh item yang diuji cobakan menunjukkan bahwa mayoritas cukup valid sebagaimana tampak pada tabel berikut.

Tabel Hasil Uji Validitas

\footnotetext{
${ }^{31}$ Sugiyono, MetodePenelitian Pendidikan (Bandung: Alfabeta, 2010), 24.
}

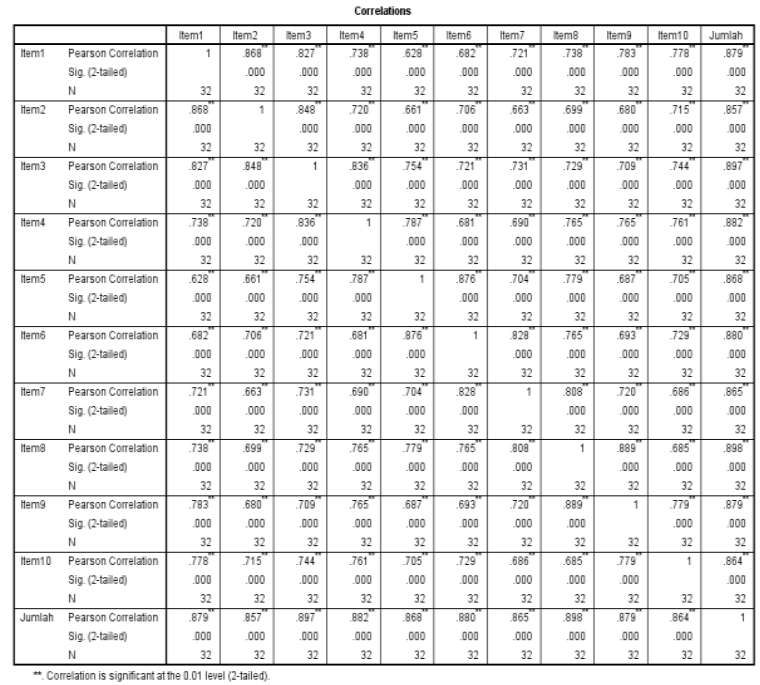

Uji reliabilitas terhadap instrumen ini dilakukan uji Cronbach's Alpha. Adapun kriteria keputusan reliabilitas instrumen dengan mengikuti ketentuan berikut.

- Jika harga r-hitung > r kritis $(0,60)$ maka item tersebut dinyatakan signifikan, jadi dapat dinyatakan reliabel sehingga layak untuk digunakan dalam penelitian

- Jika harga r-hitung < r kritis $(0,60)$ maka item tersebut dinyatakan tidak signifikan, jadi tidak cukup reliabel sehingga harus direvisi atau diganti.

Selanjutnya ringkasan hasil analisis uji reliabilitas dapat dilihat sebagaimana pada tabel berikut.

Tabel Ringkasan Hasil Uji Reliabilitas

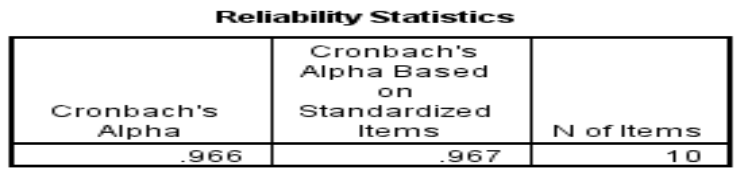

Berdasarkan ringkasan hasil analisis uji reliabilitas instrumen di atas diperoleh nilai Alpha sebesar 0,966 yang berarti jauh lebih besar dari 0,60.Dengan demikian simpulan hasil analisis dapat dinyatakan bahwa keseluruhan item instrumen adalah reliabel, dengan demikian instrumen penelitian cukup 
layak untuk dignakan mengambil data dalam penelitian.

\section{Hasil Uji Penelitian}

Uji normalitas terhadap data hasil penelitian ini dilakukan dengan teknik analisis uji Lillie (Kolmogorov-Smirnov Test), yang mana proses analisis uji normalitas. Uji normalitas ini diperlukan sebagai persyaratan bagi teknik analisis data dengan menggunakan teknik analisis uji-t sampel (Statistik Parametik). Apabila data tidak normal, maka uji-t sampel tidak tepat diterapkan.

Hipotesis uji normalitas data sebagai berikut.

$H_{0}$ : Data menyebar normal

$H_{1}$ : Data tidak menyebar normal

Hasil uji normalitas dengan mengunakan $\alpha=0,05$

Adapun ringkasan hasil uji normalitas dapat dikutip pada tabel berikut.

Tabel Ringkasan Hasil Uji Normalitas

(Pretest)

Tests of Normality

\begin{tabular}{|c|c|c|c|c|c|c|c|}
\hline & \multirow[b]{2}{*}{ Kelompok } & \multicolumn{3}{|c|}{ Kolmogorov-Smirnova } & \multicolumn{3}{|c|}{ Shapiro-Wilk } \\
\hline & & Statistic & df & Sig. & Statistic & df & Sig. \\
\hline \multirow[t]{2}{*}{ Nilai } & Kontrol & .124 & 31 & $.200^{\circ}$ & .934 & 31 & .055 \\
\hline & Eksperimen & .127 & 32 & $.200^{\circ}$ & .929 & 32 & .037 \\
\hline
\end{tabular}

Bertolak dari hasil proses analisis uji normalitas menunjukkan bahwa harga Sig diperoleh 0,200 berada di atas $\alpha 0,05$ maka disimpulkan gagal menolak $H_{0}$, yang berarti bahwa keseluruhan data menyebar normal (berdistribusi normal).

Selanjutnya dapat dipahami pula bahwa dengan terpenuhinya asumsi normalitas data di atas, maka layak dianalisis dengan uji-t sampel independen karena: 1) Kedua data menyebar normal; 2) Dua sampel tersebut bersifat independen, karena data kelompok eksperimen tidak dipengaruhi atau tidak berhubungan dengan data kelompok kontrol, dan 3) Peneliti tidak memiliki informasi mengenai ragam populasi dari kedua sampel.

\section{Uji Homogenitas}

Sebelum melakukan uji hipotesis kesamaan rerata 2 populasi dengan uji-t 2 sampel independen, masih perlu dipenuhi satu syarat lagi yakni dilakukan uji homogenitas varians. Dalam konteks penelitian ini digunakan Levene's Test Equality of Variances. Adapun dalam uji homogenitas ini dengan menggunakan $\alpha=0,05$.

Selanjutnya hasil uji homogenitas menunjukkan bahwa data dari kedua kelompok adalah homogen, seperti tampak pada kutipan ringkasan hasil uji berikut ini.

Tabel Ringkasan Hasil Uji Homogenitas (Pretest)

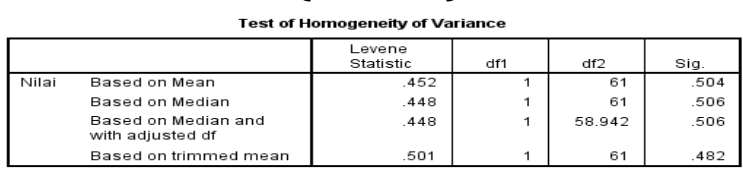

Dari hasil proses analisis uji homogenitas menggunakan Levenes's Test for Equality of Variancesmenunjukkan bahwa harga $\mathrm{F}$ diperoleh 0,452 dengan taraf signifikan sebesar 0,504 yang kedudukannya berada di atas $\alpha 0,05$ maka hasil uji dapat disimpulkan gagal menolak $H_{0}$ yang berarti bahwa kondisi kedua sampel adalah Homogen.

\section{Analisis Uji-t Pretest}

Sebagaimana di atas telah dipaparkan bahwa data-data hasil 
penelitian telah memenuhi asumsi analisis statistika parametrik, dengan uji-t 2sampel independen. Uji hipotesis dengan menggunakan $\alpha=0,05$ sebagai berikut.

$H_{0}: \mu_{\mathrm{KK}}=\mu_{\mathrm{KE}}$

$H_{1}: \mu_{\mathrm{KK}} \neq \mu_{\mathrm{KE}}$

Selanjutnya mengenai kutipan hasil analisis Pre-Tes (Tes Awal), menggunakan SPSS Versi 20. 0, dapat dipaparkan berikut ini.

\section{Tabel statistik Pretest (Tes Awal)}

\begin{tabular}{|ll|r|r|r|c|}
\multicolumn{7}{|c}{ Group Statistics } \\
\hline & Kelompok & \multicolumn{1}{|c|}{$\mathrm{N}$} & \multicolumn{1}{c|}{ Mean } & Std. Deviation & $\begin{array}{c}\text { Std. Error } \\
\text { Mean }\end{array}$ \\
\hline Nilai & Kontrol & 31 & 51.94 & 8.532 & 1.532 \\
& Eksperimen & 32 & 54.38 & 7.487 & 1.323 \\
\hline
\end{tabular}

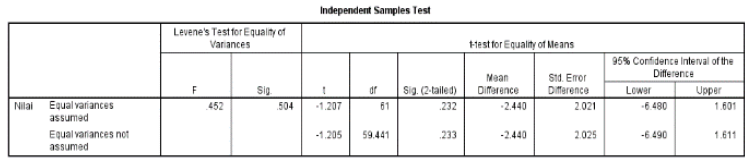

Bertolak dari hasil proses analisis data dan uji-t 2 sampel independen, diperoleh harga t sebesar -1,207 dengan signifikansi 0,232 . Selanjutnya dari hasil perbandingan dapat diketahui bahwa signifikansi t-hitung sebesar 0,232 $>\alpha 0,05$ maka hasil uji dapat disimpulkan gagal menolak $H_{0}$, yang berarti bahwa kedua sampel tidak berbeda secara signifikan.

Output diatas menunjukkan bahwa terdapat cukup bukti yang menyatakan bahwa rerata siswa pada kelompok kontrol dan rerata pada kelompok eksperimen tidak berbeda secara signifikan atau kedua kelompok memiliki performance yang sama.

\section{Uji Hipotesis}

Tabel Hasil Normalitas Posttest

\begin{tabular}{|c|c|c|c|c|c|c|c|}
\hline \multicolumn{8}{|c|}{ Tests of Normality } \\
\hline & \multirow[b]{2}{*}{ Kelompok } & \multicolumn{3}{|c|}{ Kolmogorov-Smirnov ${ }^{a}$} & \multicolumn{3}{|c|}{ Shapiro-Wilk } \\
\hline & & Statistic & df & Sig. & Statistic & df & Sig. \\
\hline \multirow[t]{2}{*}{ Nilai } & 1 & .127 & 32 & $.200^{\circ}$ & .922 & 32 & .023 \\
\hline & 2 & .129 & 31 & $.200^{\circ}$ & .918 & 31 & .021 \\
\hline
\end{tabular}

Pada tabel 4. 9 dapat dipahami bahwa analisis seperti tertuang pada kolom Kolmogorov kelompok eksperimen mempunyai taraf signifikan 0,200 sebagaimana pada kelompok kontrol juga yang kedudukannya di atas atau lebih besar dari nilai $\alpha=0,05$. Dengan demikian dapat disimpulkan bahwa data hasil penelitian berdistribusi normal.

Asumsi selanjutnya yang harus dipenuhi adalah kedua variabel yang dibandingkan adalah memiliki varians yang homogen. Untuk itu dilakukan dengan uji Levene's Test for Equality of Variance yang ternyata dari hasil uji menunjukkan bahwa untuk masingmasing kelompok yang dibandingkan adalah homogen, ringkasannya dapat dikutip seperti ditunjukkan pada tabel berikut.

Tabel Homogenitas Posttest

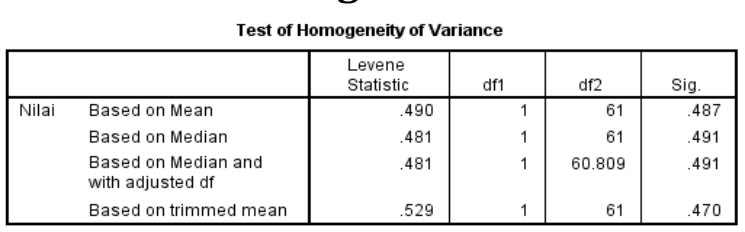

Dapat dipahami bahwa hasil analisis seperti tertuang pada tabel mempunyai taraf signifikan sebagaimana tampak pada kolom yaitu 0,487 , yang kedudukannya berada di atas atau lebih besar dari nilai $\alpha$ $=0,05$. Dengan demikian dapat disimpulkan bahwa kondisi data hasil penelitian adalah homogen.

\section{Uji t-2 Sampel Independen}

Dengan terpenuhinya asumsi penerapan uji-t2 sampel independen, maka dapat dilakukan proses analisisyang secara lengkap dimaksudkan untuk melakukan uji hipotesis penelitian. 
Selanjutnya ringkasan hasil analisis data penelitian sebagai berikut.

Tabel Statistik Posttest (Tes Akhir)

\begin{tabular}{|ll|r|r|r|c|}
\multicolumn{7}{|c|}{ Group Statistics } \\
\hline & Kelompok & \multicolumn{1}{|c|}{$\mathrm{N}$} & \multicolumn{1}{c|}{ Mean } & Std. Deviation & $\begin{array}{c}\text { Std. Error } \\
\text { Mean }\end{array}$ \\
\hline Nilai & Eksperimen & 32 & 74.38 & 7.594 & 1.342 \\
& Kontrol & 31 & 66.94 & 8.234 & 1.479 \\
\hline
\end{tabular}

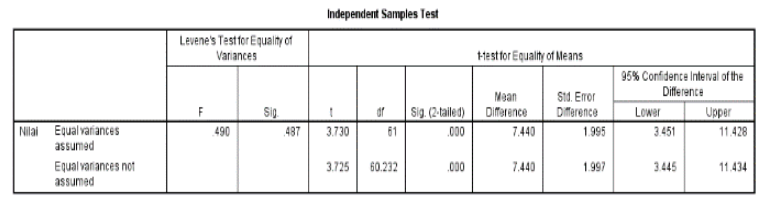

Pada tabel di atas dapat dipahami bahwa hasil analisis t-tes sebesar 3,730 berdasarkan df 61 diperoleh t hitung pada taraf signifikan 5\% sebesar 2,00 dengan demikian kedudukan t-tes 3,730 > t-tabel $2,00(\alpha=0,05)$. Dapat disimpulkan bahwa probabilitas kesalahan dalam penelitian ini masih di bawah 0,05.

Pengujian hipotesis dapat diputuskan, bahwa dengan tingginya harga t-hitung sebesar 3,730 memiliki taraf signifikan 0,000 yang ternyata kedudukannya masih jauh berada di bawah nilai $\alpha=0,05$. Dengan demikian penelitian ini berhasil menolak $H_{0}$ pada taraf signifikansi 5\%. Selanjutnya dapat disimpulkan bahwa $H_{1}$ terbukti benar.

Pada tabel di atas dapat diketahui mean dari pretes dan postes. Mean pada tabel statistik pretes kelompok eksperimen adalah 54,38 dengan Std. Deviation 7,487, dan pada tabel statistik postes kelompok eksperimen adalah 74,38 dengan Std. Deviation 7,594. Sedangkan mean pada kelompok kontrol pada tabel statistik pretes adalah 51,94 dengan Std. Deviation 8,532 dan kelas kontrol pada tabel statistik postes adalah 66,94 denan Std. Deviation 8,234. hal ini membuktikan bahwa terjadi peningkatan pada kelas eksperimen yang telah diberikan perlakuan dengan metode pemberian tugas (resitasi). Mean dari kelompok eksperimen lebih besar daripada kelompok kontrol $(74,38>66,94)$. Mean pada kelompok kontrol dengan menggunakan metode ceramah (konvensional) juga mengalami peningkatan akan tetapi peningkatan pada kelompok kontrol kurang optimal dan masih belum dapat dikatakan mencapai tujuan pembelajaran atau belum menunjukkan peningkatan yang signifikan.

Dengan demikian dapat disimpulkan kemampuan berpikir kritis siswa pada kelompok eksperimen lebih tinggi daripada kelompok kontrol. Metode pemberian tugas (resitasi) berpengaruh positif terhadap kemampuan berpikir kritis siswa.

\section{E. Diskusi Hasil Penelitian}

Pemberian motivasi pada awal pembelajaran sangat diperlukan dalam rangka menyiapkan siswa untuk menerima materi yang akan disampaikanterutama hubungannya dengan suatu permasalahan yang berkaitan dengan materi. Motivasi siswa melalui situasi menantang pada penelitian ini yaitu materi tentang globalisasi yang diberikan dalam bentuk soal tes tentang permasalahan atau fakta-fakta sesuai materi. Berdasarkan permasalahan atau fakta-fakta tersebut siswa dapat menyelesaikan permasalaha tersebut dengan mengarah pada kemampuan berpikir kritis. Pembelajaran pada penelitian ini mengacu pada SK tentang globalisasi. 
Tugas menyelesaikan masalah/soal yang diberikan dengan kemampuan berpikir kritis yang diberikan dapat memantapkan siswa dalam kemampuan belajar agar lebih kritis dalam pemikirannya. Hal ini sejalan dengan teori "seseorang dapat dikatakan dapat berpikir kritis apabila dapat menguji pengalaman, menilai pengetahuan dan gagasan dan menimbang argumen-argumen sebelum sampai pada penilaian". ${ }^{32}$

Pengalaman dan pengetahuan siswa diuji dengan menggunakan soal-soal yang mengandung pemahaman berpikir kritis.

Metode pemberian tugas (resitasi) dapat membantu siswa merealisasikan pengetahuan yang telah mereka peroleh dan dapat diterapkan kepada situasi baru, dan proses ini menuntun siswa untuk memperoleh pengetahuan baru. Dengan menggunakan metode pemberian tugas (resitasi) memungkinkan siswa itu menjadi lebih kritis dalam menyelesaikan masalah yang mereka hadapi dalam kehidupan sehari-hari.

Nilai rerata hasil belajar menggunakan metode pemerian tugas (resitasi) terhadap kemampuan berikir kritis siswa untuk menyelesaikan soal PKn tentang globalisasi sebelum diberikan pembelajaran pretest rerata nilai pada kelas kontrol yaitu 51, dan rerata nilai pada kelas eksperimen yaitu 54. Mean pada tabel statistik Pretest kelompok eksperimen adalah 54,38 dengan Std. deviation 7,497, dan Std. deviation 7,594. Sedangkan Mean kelompok kontrol pada tabel statistik Pretest adalah 51,94 dengan Std. Deviation 8,532 dan kelas kontrol

\footnotetext{
${ }^{32}$ Alec Fisher, Berpikir kritis sebuah pengantar (Jakarta: Erlangga, 2009).
}

pada tabel statistik postest adalah 66,94 dengan Std. Deviation 8,234. Nilai rerata hasil belajar menggunakan metode pemberian tugas (resitasi) terhadap kemampuan berpikir kritis siswa untuk menyelesaikan soal PKn tentang globalisasi dengan menggunakan metode resitasi rerata pada kelas kontrol yaitu 66 dan rerata pada kelas eksperimen yaitu 74. Dapat disimpulkan kemampuan berpikir kritis siswa pada kelompok eksperimen lebih tinggi daripada kelompok kontrol. Metode pemberian tugas (resitasi) berpengaruh positif terhadap kemampuan berpikir kritis siswa.

Hasil keterlaksanaan pembelajaran ini hanya untuk memastikan bahwa rancangan RPP dengan metode pemberian tugas (resitasi) yang telah dibuat dapat terlaksana sesuai dengan rencana yang telah disusun sebelumnya. Oleh karena itu hasil ini hanya dijadikan pendukung saja tidak digunakan dalam kesimpulan.

\section{F. Penutup}

Dapat disimpulkan bahwa metode pemberian tugas (resitasi) berpengaruh positif terhadap kemampuan berpikir kritis pada pembelajaran PKn siswa kelas IV Sekolah Dasar Negeri Mojoroto Kota Kediri.

Adapun saran yang dapat penulis berikan berkaitan pembelajaran sebaiknya dirancang sesuai kebutuhan dan kemampuan individu siswa. Agar pembelajaran menarik guru dapat menggunakan metode atau model pembelajaran yang dapat menarik 
perhatian siswa dan dapat meningkatkan kemampuan berpikir siswa sehingga hasil belajar siswa juga diharapkan lebih baik.

\section{G. Daftar Pustaka}

Ahmadi, Abu. Psikologi umum. Jakarta: Rineka Cipta, 2003.

Ahmadi, Abu, dan Joko Tri Prasetya. Strategi belajar mengajar. Bandung: Pustaka Setia, 2005.

Alipandie, Imansyah. Didaktik Metodik Pendidikan. Surabaya: Penerbit Usaha Nasional, 1984.

Depdiknas. "Kurikulum Tingkat Satuan Pendidikan (KTSP) Untuk Sekolah Dasar/ MI." Depdiknas, 2006.

- - - "Permendiknas RI No. 22. Tentang Standar Isi Untuk Satuan

Pendidikan Dasar Dan Menengah." Depdiknas, n.d.

-——. "UURI No. 20 Th. 2003 Tentang Sisdiknas Bab II Dasar, Fungsi dan Tujuan Pasal 3." Depdiknas, 2003.

Djahiri, A. Kosasih. Dasar-dasar Umum Metodologi dan Pengajaran Nilai Moral. Bandung: IKIP Bandung, 1995.

Fisher, Alec. Berpikir kritis sebuah pengantar. Jakarta: Erlangga, 2009.

H. A. R, Tilaar. Standarisasi Pendidikan Nasional. Bandung: Rineka Cipta, 2006.

I.LPasaribu. Didaktik dan Metodik. Bandung: Tarsito, 1986.

Mulyasa, Enco. Kurikulum berbasis kompetensi: konsep, karakteristik, dan implementasi. PT Remaja Rosdakarya, 2002.

Mustaji. "Pengembangan Kemampuan Berpikir Kritis dan Kreatif dalam Pembelajaran." Diakses 4 Juni 2017.

http://www.academia.edu/378212 6/Pengembangan_Kemampuan_Ber pikir_Kritis_dan_Kreatif_dalam_Pe mbelajaran.
Nitko, Anthony J. Educational assessment of students. ERIC, 2001. http://eric.ed.gov/?id=ED449193.

Sapriya. "Analisis Signifikasi 'Content' PKn Persekolahan Dalam Menghadapi Tuntutan Era Demokrasi dan Penegakan Hak Asasi Manusia." Jurnal Civicus 1 (2001).

Sardiman, Arief M. Interaksi \& motivasi belajar mengajar. Rajagrafindo Persada (Rajawali Pers), 2004.

Soemantri, Muhammad Numan.

Menggagas pembaharuan pendidikan IPS. Bandung: Remaja Rosdakarya, 2001.

Sudirman, N. Ilmu pendidikan. Bandung: Tarsito, 1992.

Sudjana. Metoda Statistika. 6 ed. Bandung: Tarsito, 1997.

Sugiyono. MetodePenelitian Pendidikan. Bandung: Alfabeta, 2010.

Suharsimi, Arikunto. Prosedur Penelitian Suatu Pendekatan Praktek. Jakarta: Rineka Cipta, 2006.

Suriadi. "Pembelajaran dengan Pendekatan Discovery yang Menekankan Aspek Analogi Untuk Meningkatkan Pemahaman Matematik dan Kemampuan Berpikir Kritis Siswa SMA." Universitas Pendidikan Indonesia, 2006.

Surya, Hendra. Cara Belajar Orang Genius. Jakarta: : Elex Media Komputindo, 2013.

Warsono, Hariyanto. Pembelajaran Aktif Teori dan Asesmen. Bandung: Remaja Rosdakarya, 2012.

Winataputra, Udin Saripudin, Rahmat Rahmat, Sapriya Sapriya, H. Sumardi, Syaiful Mikdar, Kuswaya Wihardit, dan Dadang Sundawa. "Materi dan pembelajaran PKN SD," 2014.

http://repository.ut.ac.id/4114/1/ PDGK4401-TM.pdf. 


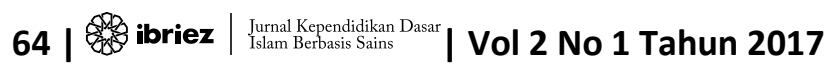

